\title{
NARCISSISTIC PERSONALITY TRAITS IN THE CONTEXT OF ACCOUNTING EDUCATION: AN APPLICATION OF THE ITEM RESPONSE THEORY
}

\section{TRAÇOS DE PERSONALIDADE NARCISISTA NO CONTEXTO DO ENSINO CONTÁBIL: UMA APLICAÇÃO DA TEORIA DA RESPOSTA AO ITEM}

\section{RASGOS DE LA PERSONALIDAD NARCISISTA EN EL CONTEXTO DE LA EDUCACIÓN DE CONTABILIDAD: UNA APLICACIÓN DE LA TEORÍA DE RESPUESTA AL ÍTEM}

Recebido em: 07/10/2018

Avaliado em: 09/05/2019

Reformulado em:11/05/2019

Aceito para publicação em: 15/07/2019

Publicado em: 30/11/2019

Editor Responsável: Marcia Zanievicz da Silva

\author{
Raimundo Nonato Lima Filho ${ }^{1}$ \\ Ariel Antônio Conceição de Souza² \\ Márcia Figueredo D'Souza ${ }^{3}$
}

\begin{abstract}
This article aims to identify the manifestation of narcissistic personality traits in 187 students of Accounting from Northeast Brazil with the use of the Narcissistic Personality Inventory. Data were analyzed with the use of the Item Response Theory, the correlation analysis and the Student $t$ test. Students showed prominent characteristics of authority and exhibitionism, with men and students of private institutions being more narcissistic. The results expand the restricted list of studies on narcissism in the national scene, seeking to contribute to discussions on the diagnosis of narcissistic personalities by educators, and to contribute to the improvement of educational processes.
\end{abstract}

Keywords: Narcissistic Personality Inventory; Gender; Higher Education Institutions; Age; Item Response Theory; Diagnosis of Narcissistic Personalities.

\section{RESUMO}

Este artigo objetiva identificar a manifestação dos traços de personalidade narcisista em 187 estudantes de Ciências Contábeis do Nordeste do Brasil com uso do Inventário de Personalidade Narcisista. Os dados foram analisados com uso da teoria da resposta ao item, da análise de correlação $\mathrm{e}$ do teste $\mathrm{t}$ de student. Os estudantes apresentaram características marcantes de autoridade e exibicionismo, com homens e alunos de instituições privadas se revelando mais narcisistas. Os resultados ampliam o restrito rol de estudos sobre narcisismo no cenário nacional, buscando contribuir com as discussões de educadores sobre as implicações de características de personalidades narcisistas no processo de ensino aprendizagem.

Palavras-chave: Inventário de Personalidade Narcisista; Gênero; Instituições de Ensino Superior; Idade; Teoria de Resposta ao Item; Diagnóstico de Personalidades Narcisistas.

\footnotetext{
${ }^{1}$ Doutor em Administração pela Universidade Federal da Bahia e em Controladoria e Contabilidade pela Universidade de São Paulo; Professor da Universidade do Estado da Bahia; E-mail: rnlfilho@gmail.com

${ }^{2}$ Mestre em Ciência Contábeis pela FUCAPE Business School; E-mail: ariel_swu@ @otmail.com

${ }^{3}$ Doutora em Controladoria e Contabilidade pela Universidade de São Paulo; Professora na Universidade do Estado da Bahia; E-mail: marciafdsouza@yahoo.com.br
} 


\section{RESUMEN}

En este artículo se objetiva identifica la manifestación de los rasgos de personalidad narcisista en 187 estudiantes de Contabilidad del noreste de Brasil con el uso del inventario de la personalidad narcisista. Los datos fueron analizados con el uso de la teoría de respuesta al ítem, el análisis de correlación y la prueba de la t de Student. Los estudiantes mostraron marcadas características de la autoridad y el exhibicionismo, con los hombres y los estudiantes de instituciones privadas está revelando más narcisista. Los resultados amplían la lista restringida de los estudios sobre el narcisismo en la escena nacional, buscando contribuir a los debates sobre el diagnóstico de la personalidad narcisista por los educadores podrían contribuir a la mejora de los procesos educativos.

Palabras clave: Inventario de Personalidad Narcisista; Género; Instituciones de Educación Superior; Edad; Teoría de Respuesta al Ítem; Diagnóstico de la Personalidad Narcisista.

\section{INTRODUCTION}

Research related to various areas of knowledge has analyzed human behavior associated with narcissistic personality (Campbell et al., 2011, Brown, Akers, \& Giacomino, 2013, Akers, Giacomino, \& Weber, 2014, Avelino Lima, 2017), both in the corporate environment and in the academic field. A recent study by the University of Science and Technology of China analyzed the influences of narcissism on the relationship between supervisors and supervisees in postgraduate courses, emphasizing that levels of narcissism are associated with negative experiences shared by students (Li, 2015).

According to Pincus et al. (2009), narcissistic traits can be pathological, being clinically defined as personality disorders, or "normal" (non-pathological), perceived as personality characteristics that have positive consequences, or cause tendencies to inappropriate behavior, suggesting violation of ethics codes in spaces where such behavior is manifested, whether in the corporate or academic context. Thus, the narcissistic personality traits are characterized by an enduring pattern of great self-importance and exaggerated sense of talent and accomplishments, and an exhibitionistic need for attention and admiration (Vandenbos, 2010).

In business environments, this construct is explored and related to leadership, exhibitionism, greatness and corporate decision-making (D'Souza, \& Jones, 2017). Narcissistic leaders are more likely to interpret the information with a self-interest bias and to make decisions based on how they will reflect on their reputation. They are concerned with controlling others, and can become paranoid about perceived enemies, especially when they are under excessive stress (D'Souza, \& Jones, 2017, Maccoby, 2004). On the other hand, they also highlight positive aspects such as strategic dynamism, vision and creativity (Maccoby, 2004).

In analyzing the academic world, Langaro (2012) attests that the narcissistic individual stands out for their self-esteem and preservation of personal interest attitudes, as well as their investment in growth and maturation; these inclinations are known as life narcissism, and they are beneficial to the academic process. In contrast, the negative aspects are observed in the sense of superiority, aggressiveness, impulsiveness, need for admiration, lack of empathy, overestimation of performance and difficulty to seek advice, negative reactions to failure and negative effects in the academic environment, given that these personality characteristics may constitute barriers to learning (Hudson, 2012).

In this perspective, narcissistic students are predisposed to present dishonest behavior in order to avoid academic failure and maintain a certain performance (Avelino, \& Lima, 2014). In order to reach their goals, they copy friends' tests, plagiarize work and co-participate in activities designed for individual development without effective contribution (Sanchez, \& Innarelli, 2012). Due to these situations, today's students and later professionals in the future, once psycho-adapted to narcissistic behaviors, may promote counterproductive impacts on organizations specifically in the accounting 
area, where performance consistent with ethical and moral principles is expected, given the skills and abilities conferred to professionals to perform their duties (Oliveira et al., 2014).

From this context, knowing the academic profile of students is relevant, specifically in this study, in the Accounting area, to identify the trais of narcissistic characteristics. This knowledge will contribute to the process of teaching, education, as well as to the personal and professional life of individuals.

With this purpose, this study has the following guiding question: How are the narcissistic personality traits revealed in students of Accounting? Thus, this research aims to understand the personal behavior of academics in order to identify how the narcissistic personality traits in students of Accounting are revealed.

This study is justified because narcissism has incipient discussion in the national context as stated by Avelino and Lima (2017), and is mostly associated with leadership studies in the organizational environment (D'Souza, \& Jones, 2017). Therefore, there is a need to understand the implications of the topic, involved in the Accounting education environment, given that students' dishonest behavior in academia may extend into the corporate environment (Avelino, 2017). In addition to that, the issue sparks reflections from corporate recruiters, academic managers, professors, and Accounting students alike (D'Souza, \& Lima, 2018).

The contribution of the study is to bring the discussion on the following subject to academia: profile of students and narcissism. In addition, it intends to contribute specifically to educators' knowledge of the subject and discuss how to deal with students with this profile.

\section{THEORY}

The origin of the term narcissism, according to Guimarães (2012), derives from a reference to the myth of Narcissus, who, in Greek mythology, was a young man who fell in love with his own reflection, and died as a result of his own fascination. Gregory (2012) ensures that the concept of narcissism is related to the Narcissus myth, as the myth, founder of a thought, brought aspects that give origin to the concept; moreover, it reinforces the initial clinical characterizations by inserting reflections on the various phenomena to which it refers.

Guimarães and Endo (2014) state that this term appears in the late nineteenth century and there is almost consensus among authors that the word's origin is attributed to two physicians: a) Havelock Ellis, using it in a psychopathological debate in 1898 to designate perverse behavior related to the myth of Narcissus; and b) Paul Nacke, a year later with reference to the text of Ellis, would have invented the word, to describe a sexual perversion. Roudinesco and Plon (1998) attributed the invention of the term to Alfred Binet in 1887, meaning a form of fetishism, which consists of taking the person as a sexual object. The term then was used by Ellis, in 1898, when he made reference to self-eroticism.

However, it is in the text entitled "Introduction to Narcissism" by Freud (1914/2010) that the subject attains prominent place among scholars in the field of psychoanalysis (Silva, 2014). According to Roudinesco and Plon (1998), the term narcissism acquired the value of a concept, libidinal phenomenon.

According to Gregory (2012), the notion of narcissism has been understood in different ways: as a sexual perversion, as an instrument at the service of the psychic subject economy, as a way of identifying a state of development. Melo Junior and Ronchi $(2013$, p. 4) endorse that "the concept of narcissism can be described as evolutionary, going through various reworkings".

According to Campbell et al. (2011) narcissism currently comprises three components: the ego (characterized by vanity, lust for power); interpersonal relationships (low levels of empathy and emotional intimacy) and self-regulation strategies (need for attention and admiration).

In accordance with the American Psychiatric Association (1994, p.1039), narcissism can be understood as an "invasive pattern of grandiosity, need for admiration and lack of empathy" and is 
classified as a personality disorder. However, Avelino and Lima (2017, p. 72) argue that this kind of behavior may present a positive aspect, "one that integrates the representations of the ego into a coherent whole, giving a sense of self-worth and value to oneself."

According to Campbell et al. (2011, p. 269), "narcissism is a concept that appears in both social personality literature, as in clinical and psychiatric literature". Pincus et al. (2009) confirm this position addressing narcissism in two poles: the pathological narcissism and normal narcissism.

D'Souza and Jones (2017) argue that narcissism, as a personality disorder, is characterized by an abnormal high level of self-esteem, arrogance, need for admiration and insensitivity, that result into conflicting interpersonal relationships. Li (2015) maintain that excessive power, manipulative behavior, superiority over ordinary people, lack of empathy and compassion are behaviors of individuals with high levels of narcissistic traits, providing negative experiences.

Narcissism in a non-clinical perspective, according to Pincus et al. (2009), is known as the normal narcissism, rated as a personality trait and studied by social psychology, while the clinical perspective is most commonly assessed in clinical research and practice. Dworkis (2012) clarifies that the high level of superiority of the narcissist contributes to the belief in their abilities, i.e., their sense self-efficacy, which can increase motivation and effort, improving their performance.

Jones and Paulhus (2011) argue for the need of professional help to deal with the clinical level of the personality disorder; on the other hand subclinical level allows the individual to live normally in society. D'Souza and Lima (2015) consider narcissism as a non-pathological trait, with different levels, which enables the observation of positive and negative behaviors, externalized by managers in businesses.

Although narcissistic behavior is inherent in every human being (Amernic, \& Craig, 2010), there is not a threshold to fix boundaries between its "normal" and "excessive" levels (Miller, \& Campbell, 2010); what may be accomplished is to classify the aspects usually present in high levels of narcissism (Johnson et al., 2013). Thus, the good side of narcissism may be revealed in the moderate level of this trait, unveiling its brilliant and cherished face for human beings and corporations (D'Souza, \& Jones, 2017).

To identify the level of healthy narcissism, Avelino and Lima (2017) point out that the Narcissistic Personality Inventory (NPI) became the most commonly used instrument with people considered "normal." This psychometric instrument was designed by Raskin and Terry in 1988, and was developed through the use of the criteria set out by the Diagnostic and Statistical Manual of Mental Disorders (DSM-III) for Narcissistic Personality Disorder (Campbell et al. 2011).

In accordance with Langaro (2012), initially, several ongoing studies - published by Raskin and Hall in 1981, and by Raskin and Terry in 1988 - produced a self-report questionnaire of 54 items. Each item consists of a pair of narcissistic and non-narcissistic statements. Later, as a result of the studies by Raskin and Terry (1988), there was a reduction from 54 to 40 items. The NPI seeks to evaluate seven subscales: authority, exhibitionism, superiority, requirement, self-sufficiency, vanity and exploitation (Rosario; White, 2005). However, some authors, through the analysis of NPI principal components and exploratory factorial analysis of the NPI scale, proposed other dimensions. Corry et al. (2008) deployed the NPI with university students, and used some studies as their bases (Raskin, \& Terry, 1988, Emmons, 1987, Kubarych, Deary, \& Austin 2004); after the factorial analysis, they proposed the "Leadership/Authority" and "Exhibitionism/Demand" dimensions. Ackerman et al. (2011), using the NPI, with the help of these studies - and those of Corry et al. (2008) - proposed the "Leadership/Authority", the "Grand Exhibitionism" and the "Demand/Exploitation" dimensions.

The "Leadership/Authority" dimension of this latter study refers to adaptive aspects of the NPI, characterized by psychologically healthy individuals who maintain positive illusions about themselves, demonstrate adaptive self-enhancement, struggle for success in contexts related to achievements, show self-esteem, extroversion and social potency; on the other hand, the "Grand Exhibitionism" and "Demand/Exploration" dimensions are related to maladaptive aspects, 
characterized by rage, antisocial tendencies, devaluation of others, demand and Machiavellianism (Ackerman et al., 2011).

On the NPI scale proposed by Raskin and Terry (1988), characteristics of dominance, assertiveness, leadership, criticism and self-confidence are associated with the "Authority" dimension; on the other hand, aspects regarding search for sensations, extroversion, and uncontrollable impulses make up the "Exhibitionism" component. According to the authors, exploitation is connected with insurgency, non-conformity, hostility, lack of consideration and tolerance towards others, while ambition, need for power, dominance, hostility, resistance and lack of self-control are associated with the "Demand" dimension. Furthermore, assertiveness, independence, self-confidence and need for accomplishment are characteristic of self-sufficiency. Lastly, vanity is related to persons feeling and being considered physically attractive, while superiority is associated with characteristics such as status capacity, social presence, self-confidence and ego inflation (Raskin, \& Terry,1988).

For the assessment of the Narcissistic Personality Inventory, the Item Response Theory (IRT) becomes essential. In accordance with Moreira Junior et al. (2015), several areas which aimed at such an assessment have used this model, since the IRT focuses on a modern psychometrics model estimation of latent traits (Nascimento et al., 2016), which are deemed to be inherent characteristics of the individual that cannot be observed directly, requiring a secondary variable for measurement (Moreira Junior et al., 2015). In accordance with Araújo, Andrade and Bortolotti (2009) observation, IRT is a methodology that proposes ways to represent the relationship between the probability of an individual giving the right answer to an item, its latent trait and characteristics of items, while providing mathematical models in the field of knowledge under study.

There are three types of models proposed by the IRT which are known as the 1,2, and 3 parameters: difficulty only; difficulty and discrimination; difficulty, discrimination and probability of right answers given by individuals of low ability (Andrade, Tavares, \& Valle, 2000).

From this perspective, in order to identify the narcissistic personality traits in a group of youngsters and adults, Langaro and Benetti (2014) conducted a study with the participation of 350 university students, aged between 18 and 30, living in a city in the northwestern region of Rio Grande do Sul, a Brazilian state; they were enrolled in academic programs from different areas of knowledge. By collecting sociodemographic data and application of the NPI, it was found that men had higher rates of narcissistic traits if compared to women; students at the age group 18-21 had higher results in the exhibitionism factor than students in the age group 22-25; a higher level of narcissism was noted in the students of the Exact Sciences than in those of the Human and Health Sciences.

Similarly, Li (2015), deploying the psychometric NPI instrument, arrived at the conclusion that males have higher levels of narcissism than females, and the higher the narcissism level of students, the lower the quality of the supervisor/supervisee relationship. Similar results were found by D'Souza and Lima (2018), when they realized that 1,404 Brazilian male students showed stronger narcissistic traits.

In light of the studies above, the following hypothesis will be tested:

$\mathrm{H}_{1}$ : Narcissistic personality traits are more expressive in male students, if compared to female students.

A study by Carneiro (2014) about the relationship between Narcissism, cognitive biases and risk in investment decisions, carried out with undergraduate students from Business Administration and Accounting courses at a Higher Education Institution in Belo Horizonte, using the NPI, highlighted that the "authority" factor, assessed on the NPI scale, stands out as a characteristic of the narcissistic trait that significantly influences the cognitive bias more than average; it also concludes that youngsters have higher narcissistic scores. 
Akers, Giacomino and Weber (2014), through the deployment of the NPI with professionals from public accountancy companies, and by examining differences of sex, age, and area of professional activity, compared their results with a previous study that analyzed Accounting students' narcissism, and found significant differences in the self-sufficiency traits and exhibitionism among students and professionals; younger professionals are more narcissistic, the NPI score decreases with age, and, among males, authority, self-sufficiency, and exploitation are more expressive than among females.

Drawing from these outcomes, this study proposes the following hypothesis:

$\mathrm{H}_{2}$ : academics at a younger age show higher narcissism scores, if compared to academics at an older age.

Finally, Brown, Akers and Giacomino (2013), when analyzing 120 Accounting students, being 61 from a public state university, and 59 from a private university, situated in the mid-west of the United States of America, found results showing that both undergraduate and postgraduate Accounting students, have a lower level of narcissism than students from other business areas. They also analyzed the difference of narcissism level in relation to sex, and found no significant differences for the total NPI score among students from Higher Education Institutions (HEI); they only identified a difference in item (10) regarding the "Leadership/Authority" dimension, where students from private HEI held higher average scores.

Against this backdrop, the following hypothesis will be tested:

$\mathrm{H}_{3}$ : there is no difference in the statistics of the total levels of narcissism among Accounting students coming from HEI, both public and private.

\section{METHODS}

In order to obtain answers to the research problem, this study adopted the survey method, which is a collection of information from individuals, groups, organizations, represented by a sample population and using a questionnaire for the data to be analyzed (Pinsonneault, \& Kraemer, 1993, Lima Filho, 2016). The approach is quantitative and descriptive. The quantitative research method is used to express in numbers the information obtained. The descriptive research method, on the other hand, provides new insights into the subject of narcissism, in order to establish and understand the relationship under study: profile of students and narcissism.

The criterion used for the removal of non-probability sampling was accessibility. The study sample consisted of 187 undergraduate students in Accounting Higher Education Institutions (HEIs) in the Northeast, public and private, aged between 18 and 43. Students had access to the printed Narcissistic Personality Inventory (NPI), an instrument that consists of a self-report questionnaire with 40 items containing narcissistic and non-narcissistic statements. The application of the questionnaire was carried out by the researcher with academics who took part in the Regional Meeting of Students from Accounting Programs - ERECIC- taking place from April 02 to 05, 2015 in NatalRN, a Brazilian city.

Data were collected through the deployment of the Narcissistic Personality Inventory, translated into Portuguese according to the back translation methodology by Pietro (1992). As cited by Lima Filho (2013), three bilingual people carried out the translation from English to Portuguese. After this translation, three other distinct bilingual people translated independently the questionnaire from Portuguese to English. Finally a last bilingual translator analyzed all translations and made the necessary adjustments obtaining a single version of the instrument in Portuguese, maintaining equivalence with the original version. 
The questionnaire was concluded in about 5 minutes and consists primarily of the participant's personal data items, followed by 40 items for participants to choose one of the options (A or B) as shown in the Frame 1:

Frame 1 - Narcissistic Personality Inventory

\begin{tabular}{|c|c|c|}
\hline \multicolumn{3}{|c|}{ Personal data } \\
\hline \multicolumn{2}{|c|}{ How old are you? } & What is your gender? Male or female? \\
\hline \multicolumn{2}{|c|}{ Is your Institution Private / Public? } & Accounting program classroom-based or an online course? \\
\hline \multicolumn{2}{|r|}{$\mathbf{A}$} & B \\
\hline 1 & I have a natural talent for influencing people. & I 'm not good at influencing people \\
\hline 2 & I am not humble / I do not have humility. & I am essentially a modest person. \\
\hline 3 & I would do almost everything at risk. & I tend to be a fairly cautious person. \\
\hline 4 & $\begin{array}{l}\text { When people compliment me I sometimes get } \\
\text { embarrassed (shame). }\end{array}$ & $\begin{array}{l}\text { I know I am good because everybody keeps telling me I } \\
\text { am. }\end{array}$ \\
\hline 5 & The idea of dominating the world horrifies me. & If I dominated the world, it would be better. \\
\hline 6 & Usually I manage to get away with trouble. & I try to accept the consequences of my behavior. \\
\hline 7 & $\begin{array}{l}\text { I prefer to be in the middle of the crowd and do not } \\
\text { show me. }\end{array}$ & I like being the center of attention \\
\hline 8 & I will be a success. & I'm not too concerned with success \\
\hline 9 & I'm not better or worse than others. & I think I am a special person. \\
\hline 10 & I do not know if I would be a good leader. & I see myself as a good leader. \\
\hline 11 & I am a confident person. & I would like to be a more confident person. \\
\hline 12 & I like to have authority over other people. & I do not mind following orders. \\
\hline 13 & I find it easy to manipulate other people. & I don't like it when I feel I am manipulating pe \\
\hline 14 & I insist on having the respect that is owed to me. & I usually have the respect that is owed to me. \\
\hline 15 & $\begin{array}{l}\text { It is with no special pleasure that I show off my } \\
\text { body. }\end{array}$ & I like to show off my body. \\
\hline 16 & I can read people like an open book. & Sometimes I find it hard to understand people. \\
\hline 17 & $\begin{array}{l}\text { If I feel competent, I assume responsibility for my } \\
\text { decisions. }\end{array}$ & I always like to take responsibility for my decisions. \\
\hline 18 & All I want is to be reasonably happy. & I want to be important to the world. \\
\hline 19 & My body is nothing special. & I like to be admiring my body. \\
\hline 20 & I try not to draw attention to me. & I like to take the chance to show me off. \\
\hline 21 & I always know what I am doing. & Sometimes I am not sure what I am doing. \\
\hline 22 & Sometimes I depend on people to do things. & I rarely depend on someone else to do things. \\
\hline 23 & Sometimes I tell good stories. & Everyone likes to hear my stories. \\
\hline 24 & I expect a lot from others. & I like to do something for people. \\
\hline 25 & I will never be satisfied until I get all that I deserve. & I enjoy the satisfactions of life as they occur. \\
\hline 26 & Compliments make me embarrassed. & I like to be praised. \\
\hline 27 & I have a strong desire for power. & Power in itself does not interest me. \\
\hline 28 & I am not concerned with always being trendy. & I like to be trendy. \\
\hline 29 & I like looking at myself in the mirror. & I do not spend much time looking at myself in the mirror. \\
\hline 30 & I really like being the center of attention. & I feel uncomfortable being the center of attention. \\
\hline 31 & I can live life the way I want. & People cannot always live as they please. \\
\hline 32 & Being an authority does not mean much to me. & People always recognize my authority. \\
\hline 33 & I would rather be a leader. & $\begin{array}{l}\text { It makes little difference to me whether I am a leader or } \\
\text { not. }\end{array}$ \\
\hline 34 & I'll be a great person. & I hope to be successful. \\
\hline 35 & People believe in what I say, I am able to convince. & I cannot convince people well. \\
\hline 36 & I am a natural leader. & Leadership is a quality that takes a long time to develop. \\
\hline 37 & $\begin{array}{l}\text { I wish that someday someone would write my } \\
\text { biography. }\end{array}$ & I do not like people to be snooping around my life. \\
\hline 38 & $\begin{array}{l}\text { When in public, I get upset when people do not } \\
\text { notice my appearance. }\end{array}$ & I do not care to go unnoticed when I go out in public. \\
\hline 39 & I am more capable than other people. & I have much to learn from other people. \\
\hline 40 & I am very similar to any other person. & I am an extraordinary person. \\
\hline
\end{tabular}

Source: Adapted from Raskin and Terry (1988). 
The NPI-40 instrument allows for the assessment of the seven narcissistic factors that were grouped into the 40 items of research. They are: Authority (measured by questions $01,08,10,11,12$, 32, 33, 36), Self-confidence (questions 17, 21, 22, 31, 34, 39), Superiority (issues 04, 09, 26, 37, 40), Exhibitionism (issues 02, 03, 07, 20, 28, 30, 38), Exploration (issues 06, 13 , 16, 23, 35), Vanity (issues 15, 19, 29) and Requirement (issues 05, 14, 18, 24, 25 and 27).

To calculate the score, Raskin and Terry (1988) codified the narcissistic statements with score 1 and the non-narcissistic statements with score 0. Participants' score is the sum of narcissistic checked items, ranging from 0 to 40 points. After calculating the score, exploratory data analysis was carried out.

The plan of analysis followed the suggestion of Ackerman, Donnellan and Robins (2012), to which we applied the 2-parameter logistic model (2PL) to the total score of the NPI, and the NPI subscales of Corry et al. (2008) and Ackerman et al. (2011). According to the authors, the decision to deploy this model is related to its frequent application to other binary answer inventories of personality (ACKERMAN et al., 2012).

The 2-parameter logistic model (2PL) is represented, according to Andrade, Tavares and Valle (2000), by the following equation:

being $i=1,2, \cdots, \mathrm{I}$, and $j=1,2, \cdots, \mathrm{n}$, where:

$$
P(U i j=1 \mid \theta j)=\frac{1}{1+e^{-D a i(\theta j-b i)}},
$$

$U i j$ is a dichotomic variable which is equal 1 , when individual $j$ answers item $i$ correctly, or 0 when individual $j$ does not answer item $i$ correctly.

$\theta j$ represents the ability (latent trait) of the individual at a certain position $\mathrm{j}$.

$P(U i j=1 \mid \theta j)$ is the probability of the individual $j$ with the ability $\theta j$ to answer item $i$ correctly, and it is named Item Response Function (IRF).

$b i$ is the difficulty (or position) parameter of item $i$, measured on the same scale of ability.

$a i$ is the discrimination (or inclination) parameter of item $i$, being proportional to the Item Characteristic Curve - ICC at point bi.

$D$ is a scale factor, constant and equal to 1 . Value 1.7 is used when one wishes that the logistic function provide results similar to those of the normal ogive model.

The difficulty parameter refer to the position in relation to the latent trait in which the probability of choosing the narcissistic option is 50\%; on the other hand, the discrimination parameter indicates that some items are more informative of the latent trait in question than other items (Ackerman et al., 2012).

Data were subject to inferential statistical analysis, and reliability was verified - which is "an assessment of the level of consistency among multiple measures of a variable" (Hair et al., 2009, p.126) - through the Cronbach's Alpha internal consistency, and the average inter-items correlation. Finally, the Hypothesis Test was carried out, with the adoption the Pearson correlation test, as well as the Student $\mathrm{t}$ test with independent data.

\section{DATA ANALYSIS AND DISCUSSION OF RESULTS}

In this chapter, it is initially presented the main characteristics of the sample followed by exploratory analyses of the psychometric properties of the NPI. It is noteworthy that the IRT model adopted in this study, which presents items of dichotomous nature, points out the relationship between the probability of an individual scoring a point, and the latent ability requested in its resolution.

The sample of this research gathers participants from all states of the Brazilian northeast, as shown in Table 1.

In regard to the type of Higher Education Institution (HEI), 71,7\% of participants are from public HEI, while 28.3\% are from private HEI. Age ranged from 18 to 43, and most of the sample consists of participants within ages 20 to 23 . 
Table 1 - Composition of the Sample

\begin{tabular}{cc}
\hline STATE & NUMBER OF RESPONDENTS \\
\hline Alagoas & 17 \\
Bahia & 28 \\
Ceará & 23 \\
Maranhão & 11 \\
Paraíba & 29 \\
Pernambuco & 29 \\
Piauí & 10 \\
Rio Grande do Norte & 24 \\
Sergipe & 16 \\
\hline GENDER & \\
\hline Male & 96 \\
Famale & 91 \\
\hline
\end{tabular}

Source: survey data (2016).

To carry out the analysis, this research uses the 2-parameter logistic model of the Item Response Theory (IRT). The scales adopted for the difficulty parameter were: very easy $(\beta \mathrm{i}<-2.0$ logits), easy ( -2.0 logits $<\beta \mathrm{i}<-1.0$ logits $)$, medium difficulty $(-1.0 \operatorname{logits}<\mathrm{Bi}<1.0$ logits $)$, difficult ( 1.0 logits $<\beta \mathrm{i}<2.0$ logits ) and very difficult ( $\beta \mathrm{i}>2.0$ logits ).

Table 2 presents descriptive statistics for the total score of the Narcissistic Personality Inventory and subscales NPI by Corry et al. (2008) and by Ackerman et al. (2011). In general, the arithmetic average of the NPI scale was 0.34 , with a standard deviation of 0.14 , which means a slight dispersion of a narcissistic behavior, already deemed to be low-level if compared to other referred studies. It presented a satisfactory Cronbach's Alpha internal consistency, given the minimum acceptable value 0.70 , different from other subscales that showed low alpha coefficients, because they are probably composed of a few items. It is noted that the subscales Leadership / Authority (M $=0.46 \mathrm{SD}=0.25 \mathrm{rij}=0.19)$ and Exhibitionism / Requirement $(\mathrm{M}=0.26 \mathrm{SD}=0.17 \mathrm{rij}=0.19)$ Corry et al. (2008) and Leadership / Authority $(\mathrm{M}=0.43 \mathrm{SD}=0.23 \mathrm{rij}=0.21)$, Great Exhibitionism $(\mathrm{M}=$ $0.28 \mathrm{SD}=0.21 \mathrm{rij}=0.23)$ and Requirement / Exploitation $(\mathrm{M}=0.32 \mathrm{SD}=0.27 \mathrm{rij}=0.31)$ Ackerman et al. (2011) showed desirable average inter-item correlations ( $\mathrm{r}$ ij); according to Clark and Watson (1995), the coefficient rij is satisfactory when it corresponds to a value in the range from 0.15 to 0.50 .

Table 2 - Descriptive statistics for the total score of the NPI, and subscales by Corry et al. (2008) and by Ackerman et al. (2011)

\begin{tabular}{|c|c|c|c|c|c|c|c|c|c|c|}
\hline \multicolumn{11}{|c|}{ Percentiles } \\
\hline & 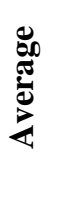 & 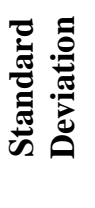 & $\stackrel{12}{N}$ & in & in & 苞 & 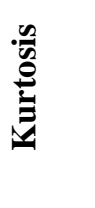 & 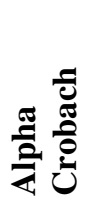 & $: 3$ & 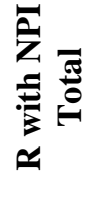 \\
\hline NPI & 0,34 & 0,14 & 0,25 & 0,32 & 0,42 & 0,60 & 1,31 & 0,76 & 0,11 & \\
\hline \multicolumn{11}{|c|}{ Sub-ranges - Corry et al. (2008) } \\
\hline Leadership/Authority & 0,46 & 0,25 & 0,33 & 0,44 & 0,67 & 0,13 & $-0,57$ & 0,67 & 0,19 & 0,82 \\
\hline Exhibitionism/Requirement & 0,26 & 0,17 & 0,14 & 0,21 & 0.36 & 0,79 & 1,06 & 0,63 & 0,19 & 0,81 \\
\hline \multicolumn{11}{|c|}{ Sub-ranges - Ackerman et al. (2011) } \\
\hline Leadership/Authority & 0,43 & 0,23 & 0,27 & 0,45 & 0,54 & 0,18 & $-0,57$ & 0,68 & 0,21 & 0,87 \\
\hline Great Exhibitionism & 0,28 & 0,21 & 0,10 & 0,30 & 0,40 & 0,75 & 0,23 & 0,63 & 0,23 & 0,78 \\
\hline Requirement/Holding & 0,32 & 0,27 & 0,00 & 0,25 & 0,50 & 0,41 & $-0,75$ & 0,37 & 0,31 & 0,37 \\
\hline
\end{tabular}

Note. $\alpha=$ coefficient of Cronbach's alpha;rij = inter-items average correlation.

Source: survey data (2016).

The extent to which the total score of the items of the NPI can be considered one-dimensional was rated by using the bi-factor model. The assumption of unidimensionality means that only a latent ability can be measured by the set of items that make up the test. In a restricted bi-factor model, each 
item is specified to be loaded on a general factor and a factor of subscale. The loadings on the general factor that is greater than or equal to 0.50 are considered strong; the same applies when the subscale factors exceed the value of the general factor.

The examination of the factorial loadings of the subscales showed that some items had loadings that exceed the General factor values. There are also minimum differences between loadings on the General factor and loadings in the one-dimensional model. This suggests that the total NPI score can be considered one-dimensional (a single common factor), enough for the analysis of the IRT, where the bi-factor model will allow for the understanding of which factors are influencing the scores of narcissism, taking into consideration that multidimensional data can produce interpretable scale scores. However, an inspection of the loadings on the General factor in bi-factorial model suggests that the latent trait is defined primarily by content related to leadership and attention-seeking behavior, verified in items $(01,03,07,10,28,30,32,36$ and 38), related to those variables that have strong loadings and are related to traces of authority and Exhibitionism, which according to Raskin and Terry (1988), is characterized by dominance, assertiveness, leadership, criticality, selfconfidence, search for sensations, extroversion and impulsiveness.

After the application of the 2PL model in the total NPI score, 12 items were found with values for the $\mathrm{X}^{2}$ adjustment item greater than or equal to 100 (items $01,07,09,10,11,12,26,27,30,32$, 33 and 36). This means that from the 40 items that compose the NPI, 28 items indicate that the estimated parameters have questionable validity, that is, at least in the context of this research they don't accurately represent how participants responded to the questionnaire items (REISE, 1990). It is important to note that 7 out of the 12 items are associated with the appearance of authority, showing features mentioned in the previous paragraph. It was observed that in relation to the difficulty just an item belonged to the "easy" scale (item 8), indicating that the respondents chose a narcissistic option ("I'm going to be a success") easily, and six items (02, 14, 21, 24, 25 and 38) belonged to the "most difficult" scale, that is, they had greater difficulty in selecting the narcissistic option of these items.

The research found that many of the simplest items belong to the subscales of Authority and Self-confidence by Raskin and Terry (1988). These items reflect positive attitudes towards one's self, covered in Chapter 1 of this study. The items that are in the average range of difficulty reflect features of Exploitation, Showboating and Superiority. These items contain self-affirmations, which refer to grandiosity and imply a sense of specialness and easy control over other people. The items with a higher degree of difficulty belong to the scales of Exhibitionism and Requirement. These items represent shocking and great self-affirmations, for example, item 7 ("I like to be the center of attention"), which explains the resistance to select this option.

A variety of items showed demanding individuals, on average and above average levels of the personality trait. According to Table 2, the most discriminatory items were those which reflected aspects of leadership and need for attention. This demonstrates that the traits of Leadership/Authority are gaining a particular aspect on NPI, putting in evidence the question as to whether these elements should be considered narcissistic. Note that some items linked to the subscales of Requirement and Self-confidence by Raskin and Terry (1988) presented low discriminating values (items 14, 17, 22, and 24), in other words, these items are less informative of the latent trait level in question than the others.

In this research, along with the study of Ackerman et al. (2012), the analysis of the NPI subscale of Raskin and Terry (1988) and the subscales of Ackerman et al. (2011) were used, referring to a previous study on the measurement of the NPI by Corry et al. (2008), for better accuracy in the results, as shown in Tables 3 and 4.

After applying the 2PL model in the Leadership/Authority subscale, one could conclude that all items had $\mathrm{X}^{2}$ values over 100 , with the exception of item 8 , indicating that the parameters of these items are validated for analysis. Furthermore, in the application of the 2PL model on the subscale Exhibitionism/Requirement, it turned out that 10 items had $\mathrm{X}^{2}$ values over 100 (items 3, 4, 7, 15, $19,20,28,29,30$ and 38), suggesting, in a general way, the manifestation of traits related to vanity, 
need for deserving respect and a willingness to manipulate and take advantage of others, which, according to Ackerman et al. (2011), corresponds to socially negative elements of narcissism. In the statistics of difficulty, one realizes that item 8 belongs to the "easy" scale because item 24 is in the range "very difficult", meaning that respondents had greater difficulty in selecting a narcissistic option ("I hope a lot from other people").

Table 3 - Logistic model of 2 parameters ( 2 PL) for the NPI subscales of Leadership/Authority and Exhibitionism/Requirement by Corry et al. (2008)

\begin{tabular}{|c|c|c|c|c|c|c|}
\hline & & \multicolumn{5}{|c|}{ 2PL Model } \\
\hline & Item & $\mathrm{X}^{2}$ & $\beta$ & $\sigma \beta$ & $A$ & $\sigma \alpha$ \\
\hline \multirow{9}{*}{$\begin{array}{l}\text { Leadership/ } \\
\text { Authority }\end{array}$} & 1 & 280,75 & $-0,91$ & 0,02 & 1,45 & 0,03 \\
\hline & 8 & 96,43 & $-1,27$ & 0,03 & 0,54 & 0,02 \\
\hline & 10 & 835,37 & $-0,17$ & 0,01 & 2,65 & 0,06 \\
\hline & 11 & 311,43 & 0,05 & 0,01 & 1,48 & 0,03 \\
\hline & 12 & 654,64 & 0,06 & 0,01 & 1,73 & 0,03 \\
\hline & 27 & 374,97 & 0,49 & 0,02 & 1,31 & 0,03 \\
\hline & 32 & 451,64 & 0,93 & 0,02 & 2,21 & 0,05 \\
\hline & 33 & 392,42 & 0,06 & 0,01 & 1,68 & 0,04 \\
\hline & 36 & 445,59 & 1,30 & 0,03 & 2,33 & 0,05 \\
\hline \multirow{7}{*}{ Exhibitionism/ } & 3 & 148,85 & 2,09 & 0,06 & 0,89 & 0,02 \\
\hline & 4 & 114,38 & 1,41 & 0,03 & 0,82 & 0,02 \\
\hline & 7 & 637,90 & 0,53 & 0,01 & 2,21 & 0,06 \\
\hline & 14 & 47,71 & 2,54 & 0,14 & 0,39 & 0,02 \\
\hline & 15 & 494,96 & 1,20 & 0,02 & 1,47 & 0,04 \\
\hline & 19 & 387,54 & 0,70 & 0,02 & 1,25 & 0,03 \\
\hline & 20 & 349,76 & 1,55 & 0,03 & 1,82 & 0,04 \\
\hline \multirow[t]{7}{*}{ Requirement } & 24 & 22,96 & 3,30 & 0,19 & 0,39 & 0,02 \\
\hline & 25 & 68,72 & 2,75 & 0,10 & 0,67 & 0,02 \\
\hline & 28 & 128,40 & 0,90 & 0,04 & 1,01 & 0,02 \\
\hline & 29 & 378,87 & $-0,29$ & 0,02 & 1,25 & 0,03 \\
\hline & 30 & 713,43 & 0,34 & 0,01 & 2,66 & 0,08 \\
\hline & 38 & 292,83 & 1,69 & 0,04 & 1,60 & 0,04 \\
\hline & 39 & 78,10 & 2,40 & 0,10 & 0,59 & 0,02 \\
\hline
\end{tabular}

Note. $\mathrm{B}=$ parameter difficulty; $\sigma \beta=$ standard error for the parameter of difficulty; $\alpha=$ parameter of discrimination $\sigma \alpha=$ standard error for the parameter of discrimination

Source: survey data (2016)

In relation to discrimination statistics, from the 23 items, only 5 items $(8,14,24,25$ and 39) present no satisfactory values to discriminate the traits of Leadership/Authority and Exhibitionism/Requirement among the participants.

Similarly, the 2PL model was applied to the Leadership/authority subscale and it showed that ten items had values $\mathrm{X}^{2}$ over 100 (items $1,5,10.11,12,27,32,33,34$ and 36), with the exception of item 40, so the parameters are validated to analyze the latent traits in question. These items indicate traces related to self-esteem, extroversion, social power, which are considered as "adaptive" aspects of the NPI (Ackerman et al., 2011). On the other hand, the "maladaptive" aspects are allied with the components Great Exhibitionism and Requirement/Exploitation, as seen in Table 4, and point to items that show low levels of information about the parameters. Statistics of item 36 indicates that respondents had difficulty in selecting a narcissistic option ("I am a born leader"). In the parameter "discrimination" only item 40 is not satisfactory to discriminate the addressed characteristic.

In order to test the first hypothesis (H1), the Student t-test was applied with independent data. This hypothesis argues that the traits of narcissism are more expressive in male students, when compared to females. This same test was used to evaluate the variables: type of HEI and NPI. 
Table 4 - Logistic model of 2 parameters (2 PL) for the NPI subscales of Leadership/authority, Great Exhibitionism and Requirement/Exploitation of Ackerman et al. (2011)

\begin{tabular}{|c|c|c|c|c|c|c|}
\hline & \multirow[b]{2}{*}{ Item } & \multirow[b]{2}{*}{$X^{2}$} & \multicolumn{4}{|c|}{ Model 2PL } \\
\hline & & & $B$ & $\Sigma \beta$ & $\alpha$ & $\sigma \alpha$ \\
\hline \multirow{11}{*}{ Leadership / Authority } & 1 & 209,55 & $-0,90$ & 0,02 & 1,48 & 0,03 \\
\hline & 5 & 102,45 & 0,75 & 0,03 & 0,83 & 0,02 \\
\hline & 10 & 594,01 & $-0,16$ & 0,01 & 2,81 & 0,06 \\
\hline & 11 & 203,58 & 0,05 & 0,01 & 1,48 & 0,03 \\
\hline & 12 & 278,26 & 0,06 & 0,01 & 1,63 & 0,03 \\
\hline & 27 & 222,63 & 0,49 & 0,02 & 1,28 & 0,03 \\
\hline & 32 & 436,53 & 0,93 & 0,02 & 2,21 & 0,05 \\
\hline & 33 & 270,55 & 0,06 & 0,01 & 1,58 & 0,04 \\
\hline & 34 & 104,90 & $-0,27$ & 0,02 & 0,90 & 0,02 \\
\hline & 36 & 366,48 & 1,28 & 0,03 & 2,42 & 0,05 \\
\hline & 40 & 75,16 & 0,37 & 0,02 & 0,71 & 0,02 \\
\hline \multirow{10}{*}{ Great Exhibitionism } & 4 & 134,28 & 1,36 & 0,03 & 0,87 & 0,02 \\
\hline & 7 & 719,09 & 0,52 & 0,01 & 2,25 & 0,07 \\
\hline & 15 & 584,93 & 1,19 & 0,02 & 1,51 & 0,04 \\
\hline & 19 & 472,80 & 0,65 & 0,02 & 1,37 & 0,03 \\
\hline & 20 & 333,57 & 1,59 & 0,03 & 1,74 & 0,04 \\
\hline & 26 & 130,21 & $-0,45$ & 0,02 & 0,84 & 0,02 \\
\hline & 28 & 1237,17 & 0,89 & 0,04 & 1,02 & 0,02 \\
\hline & 29 & 498,36 & $-0,28$ & 0,02 & 1,37 & 0,03 \\
\hline & 30 & 761,32 & 0,34 & 0,01 & 2,59 & 0,08 \\
\hline & 38 & 405,47 & 1,84 & 0,04 & 1,40 & 0,04 \\
\hline \multirow{4}{*}{ Requirement / Exploration } & 13 & 3357,41 & 0,89 & 0,03 & 0,62 & 0,02 \\
\hline & 14 & 7825,83 & 1,08 & 0,03 & 1,06 & 0,03 \\
\hline & 24 & 4624,44 & 1,14 & 0,03 & 1,42 & 0,06 \\
\hline & 25 & 3793,82 & 1,16 & 0,02 & 2,53 & 0,13 \\
\hline
\end{tabular}

Note. $\beta=$ parameter difficulty; $\sigma \beta=$ standard error for the parameter of difficulty; $\alpha=$ parameter of discrimination; $\sigma \alpha=$ standard error for the parameter of discrimination

Source: survey data (2016)

Table 5 indicates that the sample showed little difference in gender distribution of participants, enabling a better analysis of the NPI averages, which in the case of males corresponded to 14.40 . This result is $11.4 \%$ higher than the average NPI of the female gender (12.76). These averages are similar to those averages $($ men $=14.24 /$ women $=11.74)$ observed in the study of Langaro and Benetti $(2014)$. It's important to note that the scores in this study ranged from 1 (one) to 39 (thirty-nine) points.

Table 5 - Gender X NPI

\begin{tabular}{cccccc}
\hline & Gender & $\mathrm{N}$ & Average & Standard Deviation & Average Error \\
\hline \multirow{2}{*}{ NPI } & Male & 96 & 14,4063 & 5,85361 & 0,59743 \\
& Female & 91 & 12,7692 & 5,08173 & 0,53271 \\
\hline
\end{tabular}

Source: survey data (2016)

The first hypothesis test (Table 6) revealed that men present higher levels of NPI in relation to women and according to Akers, Giacomino and Weber (2014) men are authoritarian, more selfreliant, exploitative and have a greater sense of entitlement. This result is aligned with the studies of Langaro and Benetti (2014) and $\mathrm{Li}$ (2015) that showed higher rates of narcissistic traits in the male 
gender. This confirmation may be linked to the fact that women are more likely to develop behaviors of affection, empathy and honesty, in contrast to the male gender, which tends towards behaviors linked to competitiveness (Langaro, \& Benetti, 2014; Lima Filho, \& Bruni, 2017) and even dishonest behaviors (Avelino, \& Lima, 2017) in a search for personal interests.

Table 6 - Test of independent samples

\begin{tabular}{|c|c|c|c|c|c|c|c|c|c|c|}
\hline & & \multicolumn{2}{|c|}{$\begin{array}{c}\text { Levene test for } \\
\text { equality of } \\
\text { Variances } \\
\text { equal t test } \\
\text { medium }\end{array}$} & \multicolumn{7}{|c|}{ Equal $t$ average test } \\
\hline & & \multirow[t]{2}{*}{$\mathrm{F}$} & \multirow[t]{2}{*}{ Sig. } & \multirow[t]{2}{*}{$\mathrm{t}$} & \multirow[t]{2}{*}{ Df } & \multirow[t]{2}{*}{$\begin{array}{l}\text { SIG. } \\
\text { (two- } \\
\text { tailed) }\end{array}$} & \multirow[t]{2}{*}{$\begin{array}{l}\text { Average } \\
\text { difference }\end{array}$} & \multirow[t]{2}{*}{$\begin{array}{c}\text { Error } \\
\text { difference }\end{array}$} & \multicolumn{2}{|c|}{$\begin{array}{c}95 \% \text { Confidence } \\
\text { interval of the } \\
\text { difference }\end{array}$} \\
\hline & & & & & & & & & Inferior & Superior \\
\hline \multirow{2}{*}{ NPI } & $\begin{array}{l}\text { Equal variance } \\
\text { assumption }\end{array}$ & 1,526 & 0,218 & 2,037 & 185 & 0,043 & 1,63702 & 0,80347 & 0,05188 & 3,22 \\
\hline & $\begin{array}{c}\text { Equal variance not } \\
\text { assumed }\end{array}$ & & & 2,045 & 183,6 & 0,042 & 1,63702 & 0,80044 & 0,05778 & 3,216 \\
\hline
\end{tabular}

Source: survey data (2016).

In relation to age and NPI score variables $(\mathrm{H} 2)$, the test of the Pearson correlation coefficient (r) was applied, which is best appointed for psychological testing. According to Chen and Popovic (2002), this is the most frequently used statistical instrument deployed to describe the relationship among variables.

Table 7 - Hypothesis testing $\mathbf{H 2}$

\begin{tabular}{llc}
\hline & & Age \\
\hline & Pearson Correlation & $-0,078$ \\
& Sig. (two-tailed) & 0,290 \\
NPI & Sum of squares and cross-Products & $-304,925$ \\
& Covariance & $-1,639$ \\
& $\mathrm{~N}$ & 187 \\
\hline
\end{tabular}

Source: survey data (2016)

Therefore, in Table 7 Age variables and NPI did not show statistically significant correlation (SIG. 29\%). For this reason, it can be concluded that there is no significant difference between the variables, at least in the context of this research. The sample has a raised concentration in ages 20 to 23 , i.e. a high concentration in a narrow age range, which may have influenced this result. Probably in a sample involving a larger group and with a regularity in the distribution by age the results may be different.

Table 8 - Type of HEI (Institution of higher education) X NPI

\begin{tabular}{lccccc}
\hline & Tope: IHE & N & Average & Standard Deviation & Medium Error \\
\hline \multirow{2}{*}{ NPI } & Public & 134 & 13,4627 & 5,29812 & 0,45769 \\
& Private & 53 & 13,9811 & 6,14094 & 0,84352 \\
\hline
\end{tabular}

Source: survey data (2016)

Table 8 shows that the number of respondents from public Higher Education Institutions was superior to that of private ones; moreover, it is noted that there is not a significant difference between the averages of the HEIs types, which is compatible with the distribution of the study of Brown, Akers and Giacomino (2013). However, it is important to consider that even with a smaller amount, participants from the private institutions obtained an average above the one found among students from the public institutions. In the study of Brown, Akers and Giacomino (2013) the findings were different $($ public $=15.83$, private $=15.66)$. 
Table 9 - Test of independent samples

\begin{tabular}{|c|c|c|c|c|c|c|c|c|c|c|}
\hline & & \multicolumn{2}{|c|}{$\begin{array}{l}\text { Levine test for } \\
\text { equality of } \\
\text { Variances } \\
\end{array}$} & \multicolumn{7}{|c|}{ Test $t$ of equality of averages } \\
\hline & & \multirow[t]{2}{*}{$\mathrm{F}$} & \multirow[t]{2}{*}{ Sig. } & \multirow[t]{2}{*}{$\mathrm{t}$} & \multirow[t]{2}{*}{ Df } & \multirow{2}{*}{$\begin{array}{l}\text { Sig. } \\
\text { (two- } \\
\text { tailed) } \\
\end{array}$} & \multirow{2}{*}{$\begin{array}{c}\text { Average } \\
\text { Difference }\end{array}$} & \multirow{2}{*}{$\begin{array}{c}\text { Error } \\
\text { difference }\end{array}$} & \multicolumn{2}{|c|}{$\begin{array}{l}95 \% \text { Confidence } \\
\text { interval of the difference }\end{array}$} \\
\hline & & & & & & & & & Less & Higher \\
\hline \multirow{2}{*}{ NPI } & $\begin{array}{c}\text { Equal variance } \\
\text { assumption }\end{array}$ & 0,046 & 0,830 & $-0,576$ & 185 & 0,565 & $-0,51845$ & 0,90025 & $-2,29453$ & 1,25764 \\
\hline & $\begin{array}{l}\text { Equal variance } \\
\text { not assumed }\end{array}$ & & & $-0,540$ & 84,26 & 0,590 & $-0,51845$ & 0,95969 & $-2,42681$ & 1,38992 \\
\hline
\end{tabular}

Source: survey data (2016)

Significance levels of Table 9 show the lack of statistically significant differences between the types. What we can conclude is that among students from HEIs, the differences can be found in the seven categories covered by narcissism.

\section{CONCLUSIONS}

This research aimed to identify the manifestation of narcissistic personality traits in Accounting students. In order to achieve this goal, the Narcissistic Personality Inventory (NPI) psychometric instrument was applied, through which latent traits were estimated by means of the 2parameter logistic model (2PL) of the Item Response Theory (IRT).

In response to the problematic raised by this study, the narcissistic traits are more evident in males than in females. Participants from private HEI revealed a narcissistic average higher than that of students from public HEI, but with no statistical difference. In regard to age and the NPI, the conclusion was that there is no significant difference between these variables. Therefore, principally male students are dominant, assertive, self-confident, and extroverted. According to Brown, Akers and Giacomino (2013), these are characteristics of leaders, given that the narcissistic factors of Authority and Exhibitionism are key in their personality. These findings allow educators to recognize (so far) unknown aspects inherent in students, which allow them to adapt their teaching styles according to the profile of students they are teaching.

Students that checked items with contents related to Leadership/Authority traits were identified as extroverted, having self-esteem, and struggling for success; the items which suggested the manifestation of traits related to vanity, manipulation, devaluation of others, and demand, connected with the Exhibitionism/Demand scale, were also selected.

Therefore, the results of this research prompt a reflection for the teaching-learning process in Accounting, demonstrating that narcissism is a psychological aspect present in every person's behavior, being beneficial or counterproductive, depending on the level of manifestation. According to Avelino and Lima (2017), although they do not show potential experienced suffering, narcissistic individuals may need special attention. Furthermore, according to the authors, by identifying the maladaptive aspects in students, staff from HEI will be able to search alternative ways to help learners to cope with this situation in academic environments (Avelino, \& Lima, 2017).

This research presented limitations as the sample was comprised of participants from an Accounting event, that is, the criterion used was accessibility. A study involving a random sample of students can reach a greater number of participants as well as different results. In relation to the line of research, the limitation was the amount of studies involving narcissism and Accounting at the national level. For this reason, it is necessary to carry out further studies with this theme, since the highest concentration of articles is published in international journals.

For future research, the development of studies on the same theme in other Brazilian regions is recommended. Comparing Accounting students with other business areas (economics, marketing, management) or comparing accountants in different levels of education (undergraduate, Master's, 
doctorate). In short, the importance of behavioral study in Accounting is evidenced, since the results may contribute to academic and continuing education.

\section{REFERENCES}

Ackerman, R. A., Donnellan, M. B., \& Robins, R. W. (2012). An item response theory analysis of the Narcissistic Personality Inventory. Journal of personality assessment, 94(2), 141-155.

Ackerman, R. A., Witt, E. A., Donnellan, M. B., Trzesniewski, K. H., Robins, R. W., \& Kashy, D. A. (2011). What does the narcissistic personality inventory really measure? Assessment, 18(1), 67-87.

Akers, M. D., D. E. Giacomino, J. Weber. 2014. Narcissism in Public Accounting Firms. Accounting and Finance Research 3(3), 170-178.

American Psychiatric Association. (1994). Diagnostic and statistical manual of mental disorders. 4. ed. Washington: DC.

Amernic, J. H., \& Craig, R. J. (2010). Accounting as a facilitator of extreme narcissism. Journal of Business Ethics, 96(1), 79-93.

Andrade, D. F., Tavares, H. R., \& Valle, R. C. (2000). Teoria da resposta ao item: conceitos e aplicações. Associação Brasileira de Estatística, São Paulo.

Araujo, E. A. C., Andrade, D. F., \& Bortolotti, S. L. V. (2009). Teoria da resposta ao item. Revista da Escola de Enfermagem da USP, 43(1), 1000-1008.

Avelino, B. C. (2017). Olhando-se no espelho: uma investigação sobre o narcisismo no ambiente acadêmico (Tese de Doutorado). Universidade de São Paulo, Programa de Pós-Graduação em Controladoria e Contabilidade, São Paulo.

Avelino, B. C., \& de Lima, G. A. S. F. (2017). Narcisismo e desonestidade acadêmica. Revista Universo Contábil, 13(3), 70-89.

Avelino, B. C., \& Lima, G. A. S. F. (2014). A influência do narcisismo no ambiente acadêmico: aspectos relacionados à desonestidade. In Anais, $14^{\circ}$ Congresso USP de Controladoria e Contabilidade, São Paulo. São Paulo.

Brown, J., Akers, M. D., \& Giacomino, D. E. (2013). Narcissism and Accounting Majors. American Journal of Business Education, 6(3), 375-384.

Campbell, W. K., Hoffman, B. J., Campbell, S. M., \& Marchisio, G. (2011). Narcissism in organizational contexts. Human Resource Management Review, 21(4), 268-284.

Carneiro, A. K. N. (2014). Narcisismo, vieses cognitivos e risco em decisões de investimento (Dissertação de Mestrado). Faculdade Novos Horizontes, Programa de Pós-Graduação em Administração, Belo Horizonte.

Chen, P. Y., \& Popovic, P. M. (2002). Correlation: parametric and nonparametric measures. Sage University papers series. Quantitative Applications in the Social Sciences, 7(139), 1-95.

Clark, L. A., \& Watson, D. (1995). Constructing validity: Basic issues in objective scale development. Psychological assessment, 7(3), 309.

Corry, N., Merritt, R. D., Mrug, S., \& Pamp, B. (2008). The factor structure of the Narcissistic Personality Inventory. Journal of Personality Assessment, 90(6), 593-600.

D'Souza, M. F., \& de Lima, G. A. S. F. (2018). Escolha de carreira: o Dark Triad revela interesses de estudantes de Contabilidade. Revista de Contabilidade e Organizações, 12, e151837.

D’Souza, M. F., \& Jones, D. N. (2017). Taxonomia da rede científica do Dark Triad: revelações no meio empresarial e contábil. Revista de Educação e Pesquisa em Contabilidade, 11(3), 296-313.

D’Souza, M. F., Lima, G. A. S. F. D., Jones, D. N., \& Carre, J. R. (2019). Eu ganho, a empresa ganha ou ganhamos juntos? traços moderados do dark triad e a maximização de lucros. Revista de Contabilidade \& Finanças, 30(79), 123-138.

D'Souza, M., \& Lima, G. A. S. F. D. (2015). The dark side of power: the Dark Triad in opportunistic decision-making. Advances in Scientific and Applied Accounting, 8(2), 135-156.

Dworkis, K. K. (2012). The interactive effects of incentive threshold and narcissism on managerial decision-making (Ph.D Dissertation). University of Southern California, Ph.D in Accounting, California.

Emmons, R. A. (1987). Narcissism: Theory and measurement. Journal of Personality and Social Psychology, 52(1), 11. 
Freud, S. (1914/2010). Introdução ao narcisismo. Sigmund Freud, obras completas, 12, São Paulo: Companhia das Letras.

Gregório, A. R. B. (2012). Narcisismo e organização narcísica no filme o cisne negro (Dissertação de Mestrado). Instituto Universitário de Ciências Psicológicas, Sociais e da Vida, Portugal.

Guimarães, L. M. (2012). Três estudos sobre o conceito de narcisismo na obra de Freud: origem, metapsicologia e formas sócias (Dissertação de Mestrado). Universidade de São Paulo, Programa de Pós-Graduação em Psicologia), São Paulo-SP.

Guimarães, L. M., \& Endo, P. C. (2014). A origem da palavra narcisismo. Revista Latinoamericana de Psicopatologia Fundamental, 17(3), 431-449.

Hair, J. F., Black, W. C., Babin, B. J., Anderson, R. E., \& Tatham, R. L. (2009). Análise Multivariada de Dados. Bookman Editora.

Hudson, E. J. (2012). Understanding and exploring narcissism: impact on students and college campuses. Paper (Bachelor of Arts), Claremont Colleges, Claremont-California.

Johnson, E. N., Kuhn Jr, J. R., Apostolou, B. A., \& Hassell, J. M. (2012). Auditor perceptions of client narcissism as a fraud attitude risk factor. Auditing: A Journal of Practice \& Theory, 32(1), 203-219.

Jones, D. N., \& Paulhus, D. L. (2011). Differentiating the dark triad within the interpersonal circumplex. In Horowitz, L.M., \& Strack, S. (Org.). Handbook of interpersonal psychology. New York: Wiley and Sons.

Kubarych, T. S., Deary, I. J., \& Austin, E. J. (2004). The Narcissistic Personality Inventory: Factor structure in a non-clinical sample. Personality and Individual Differences, 36(4), 857-872.

Langaro, F. N. (2012). As manifestações do vazio na sociedade contemporânea (Dissertação de Mestrado). Universidade do Vale do Rio dos Sinos, Programa de Pós-Graduação em Psicologia Clínica, São Leopoldo-RS.

Langaro, F. N., \& da Cruz Benetti, S. P. (2014). Subjetividade contemporânea: narcisismo e estados afetivos em um grupo de adultos jovens. Psicologia Clínica, 26(2), 197-215.

$\mathrm{Li}, \mathrm{Z}$. (2015). The analysis of the influences of student's narcissistic personality traits to negative mentoring experiences. Creative Education, 6(03), 350.

Lima Filho, R. N. (2013). Empreendendo sobre o empreender e pensando sobre o pensar: um estudo sobre características empreendedoras e metacognição (Tese de Doutorado). Universidade Federal da Bahia, Programa de Pós-Graduação em Administração, Salvador.

Lima Filho, R. N. (2016). Autorregulando e autodeterminando: duas formas de alunos de pósgraduação aprenderem a aprender contabilidade (Tese de Doutorado). Universidade de São Paulo, Programa de Pós-Graduação em Controladoria e Contabilidade, São Paulo.

Lima Filho, R. N., \& Bruni, A. L. (2017). Metacognition in Entrepreneurs: Psychometric Diagnostic Associated to Age and Sex. REAd - Revista Eletrônica de Administração, 23(spe), 345-370.

Maccoby, M. (2004). Narcissistic leaders: the incredible pros, the inevitable cons. The Harvard Business Review, 78(1), 68-78.

Melo Junior, J. S. M, \& Ronchi, C. C. (2013). Liderança e narcisismo: indissociabilidade para interpretação no ambiente organizacional. In Anais $38^{\circ}$ Encontro da Anpad, Rio de Janeiro. ANPAD: Rio de Janeiro.

Miller, J. D., \& Campbell, W. K. (2010). The case for using research on trait narcissism as a building block for understanding narcissistic personality disorder. Personality Disorders: Theory, research, and treatment, 1(3), 180.

Moreira Junior, F. D. J., Zanella, A., Lopes, L. F. D., \& Seidel, E. J. (2015). Evaluación de satisfacción de alumnos a través del Modelo de Respuesta Gradual de la Teoría de Respuesta al Ítem. Ensaio: Avaliação e Políticas Públicas em Educação, 23(86), 129-158.

Nascimento, J. C. H. B., Bernardes, J. R., de Sousa, W. D., \& Lourenço, R. L. (2016). Avaliação Institucional: Aplicação da Teoria da Resposta ao Item Para Avaliação Discente em Ciências Contábeis. Future Studies Research Journal: Trends and Strategies, 8(2), 117-143.

Oliveira, A. C. L., Assis, A. I. R., da Silva, D. M., \& de Oliveira Neto, J. D. (2014). Percepção dos discentes e docentes acerca da honestidade acadêmica em um curso de ciências contábeis. Revista Economia \& Gestão, 14(34), 86-118.

Pincus, A. L., Ansell, E. B., Pimentel, C. A., Cain, N. M., Wright, A. G., \& Levy, K. N. (2009). Initial construction and validation of the Pathological Narcissism Inventory. Psychological assessment, 21(3), 365 . 
Pinsonneault, A., \& Kraemer, K. (1993). Survey research methodology in management information systems: an assessment. Journal of management information systems, 10(2), 75-105.

Prieto, A. J. (1992). A method for translation of instruments to other languages. Adult Education Quarterly, 43(1), 1-14.

Raskin, R., \& Terry, H. (1988). A principal-components analysis of the Narcissistic Personality Inventory and further evidence of its construct validity. Journal of personality and social psychology, 54(5), 890.

Reise, S. P. (1990). A comparison of item-and person-fit methods of assessing model-data fit in IRT. Applied Psychological Measurement, 14(2), 127-137.

Rosario, P. M., \& White, R. M. (2005). The Narcissistic Personality Inventory: Test-retest stability and internal consistency. Personality and Individual Differences, 39(6), 1075-1081.

Roudinesco, E., \& Plon, M. (1998). Dicionário de psicanálise. Rio de Janeiro: Zahar.

Sanchez, O. P., \& Innarelli, P. B. (2012). Desonestidade acadêmica, plágio e ética. GV Executivo, 11(1), 4649.

Silva, L. B. M. (2014). A produção do conceito de narcisismo em Freud: uma análise institucional do discurso (Dissertação de Mestrado). Universidade de São Paulo, Programa de Pós-Graduação em Psicologia Escolar e do Desenvolvimento Humano, São Paulo-SP.

Vandenbos, G. R. (Org.). (2010). Dicionário de psicologia da american psychological association. Porto Alegre: Artmed. 